\title{
SIMBOLISMO NO BRASIL, SIMBOLISMO NA FRANÇA: CRÍTICA E FORMALIZAÇÃO
}

\section{Gilda Vilela Brandão*}

Resumo: Breve apanhado das práticas poéticas e da recepção crítica do Simbolismo no Brasil nas suas relações com o movimento simbolista francês, objetivando, ao mesmo tempo, rastrear as idéias críticas e as posturas estéticas desenvolvidas pelo pensamento decadente fin-de-siècle.

Palavras-chave: Simbolistas; decadentes; estilo de decadência; civilização ou progresso

Não seria arriscado supor que, afora o entusiasmo com que Roger Bastide e Nestor Vítor saudaram o talento literário de Cruz e Sousa (1862-1898) - tarefa empreendida, como é sabido, ao longo de suas experiências críticas -, as primeiras manifestações simbolistas nacionais não obtiveram, no momento de seu surgimento, uma acolhida afável por parte dos historiadores de nossa literatura. Bosi analisa assim a questão:

O tratamento que Araripe deu ao Simbolismo é índice bastante sugestivo da sua capacidade de relacionar os fenômenos estético, psicológico e cultural. Embora esta antologia não inclua textos de Araripe Jr. sobre o Simbolismo (que deverão figurar em outro volume da seleção) parece-me útil analisar o enfoque original que lhe deu o crítico. Convém lembrar que Sílvio Romero e José Veríssimo apreciaram Cruz e Sousa, apesar do simbolismo, que sempre thes pareceu uma flor "nevrótica", transplantada para o nosso meio diretamente dos "boulevards" de Paris. Araripe Jr. ficou a meio caminho entre a suspeita daqueles e a quente apologia de Nestor Vitor, o crítico mais próximo dos homens e das idéias que constituíram o movimento no Brasil. Apesar

Professora Doutora da Faculdade de Letras (Fale) e do Programa de Pósgraduação em Letras e Lingüística da Universidade Federal de Alagoas. 
de ter escrito pouco sobre os simbolistas, trata-os com uma ponta de curiosidade simpática. Se a sua formação agnóstica não compartilha dos pendores ocultistas do grupo, o seu determinismo arejado por leituras européias tão várias quer explicar também a nova e estranha poética (BOSI, 1978, p. XVII; grifos de Bosi).

Nesse sentido, são válidas as contribuições de Candido e Castello (1976), de Otto Maria Carpeaux (1953) e do próprio Bosi (1972), quando interpretam, cada um a seu modo, o problema da legitimidade da poesia simbolista em nossas letras. Para Candido e Castello, mesmo não se afinando com nossos anseios poéticos e em face ao poder de mobilização do Parnasianismo, o Simbolismo, apesar de suas excentricidades, teria repercutido na formação de nosso clima pré-modernista. Carpeaux percebe uma relação descontínua, uma "derrota" do pensamento simbolista em nossas letras. Bosi enfatiza a ausência de correlação entre pensamento estético e realidade nacional. É o que se deduz das citações abaixo:

Aliás, [o Simbolismo] foi aqui bastante medíocre, ressalvados os grandes iniciadores [Cruz e Sousa e Alphonsus de Guimaraens ]. Além disso, o seu efeito foi limitado pela aliança tácita entre Parnasianismo e o espírito acadêmico, semi-oficial. Isso fez com que permanecesse uma espécie de tendências, excêntrica ou de segunda plana [...]. Rico de experiências e variações, manifestou-se em cenáculos, revistas, livros curiosos, dando lugar a tendências subsidiárias, que extravasaram seus limites e influiram na formação de um clima prémodernista (CANDIDO; CASTELLO, 1976, p. 106).

Sobre o simbolismo brasileiro não existe livro ou estudo de extensão considerável. Esse fato é sintoma, entre outros, da derrota que sofreu no Brasil o movimento simbolista, que foi de tanta importância em outra parte [...]. O parnasianismo, sobrevivendo-se a si mesmo, continuou; e quando foi, por sua vez, derrotado, coube a vitória ao modernismo que não tinha nada nem quis nada com o simbolismo (CARPEAUX, 1953, p. 181).

O fenômeno histórico do insulamento simbolista no fim do século XIX não deve causar estranheza. 
movimento, enquanto estado de espírito, passava ao largo dos maiores problemas da vida nacional, ao passo que a literatura realista-parnasiana acompanhou os modos de pensar primeiro progressistas, depois acadêmicos, das gerações que fizeram e viveram a Primeira República (BOSI, 1971, p. 300-301).

Se tomarmos como parâmetro para nossa análise Broqueis, Faróis e Últimos sonetos, de Cruz e Sousa - alicerces da poética simbolista tal como se procedeu entre nós -, não é possível discordar desses posicionamentos críticos.

De fato, enquanto para Bilac o efeito poético advém da artesania da palavra e do trabalho de esculpir, por parte, o objeto - e, por isso, não é difícil mapear, em "Profissão de fé", traços herdados de Théodore de Banville (1823-1891) nestes versos de "Les stalactites": "Sculpteur, cherche avec soin, en attendant l'extase, / Un marbre sans défaut pour en faire un beau vase;/ Cherche longtemps sa forme et n'y retrace pas / D'amours mystérieux ni de divins combats" ["Escultor, busque com cuidado, aguardando o êxtase,/ Um mármore sem defeito para erguer um belo vaso/ Busque vagarosamente sua forma e não desenhe/ Amores misteriosos nem divinos combates"] -, ' para Cruz e Sousa o poético seria tanto mais alcançado quanto mais disperso se apresentasse o objeto, dentro do padrão estético defendido por Mallarmé (1842-1898), para quem "définir un objet c'est enlever les trois quarts de sa beauté"'["definir um objeto é retirar três quartos de sua beleza"].

A estrutura poemática de "Antífona", por exemplo, sustentase, fonicamente, em uma cadeia de assonâncias e construções anafóricas que volatizam o assunto, refluindo-o para um papel secundário, o qual termina por achar abrigo em termos e em elementos inerentes à liturgia e à dinâmica própria da simbologia judaico-cristã que o poeta parece abraçar.

Ó Formas alvas, brancas, Formas claras

Dos luares, de neves, de neblinas!...

Ó Formas vagas, fluidas, cristalinas..

Incensos dos turíbulos das aras...

Salvo indicação, todas as traduções são nossas. 
O poema ${ }^{2}$ pode ser lido como um longo salmo poético (uma antífona, como se sabe, é um curto versículo recitado ou cantado pelo celebrante antes e/ou depois de um salmo) cujo apelo à religiosidade responde à expectativa do conjunto da obra, ainda que esses vôos altos em direção à espiritualidade (os títulos das duas coletâneas são autoexplicativos nesse sentido) não impeçam, conforme se verá logo a seguir, algumas descidas sacrílegas que o poeta consegue, com maior ou menor esforço, debelar. Uma configuração de tal ordem aproximao "desta mistura simbolista do material e do espiritual", anotada por Balakian (2000, p. 88):

As flores também têm esta dupla conotação concreta $\mathrm{e}$ abstrata nas séries paralelas no poema "Antífona" do poeta brasileiro João da Cruz e Sousa (1861-1898) chamado o Cisne Negro do simbolismo.[...] Em resumo, independentemente do sentido particular usado, podemos dizer que estes poemas que [sic] são diferentes dos românticos se forem capazes de tornar efetivo de vários modos o uso do discurso equívoco: a palavra incomum, o objeto, a paisagem, o mito, a união das características abstratas cuja relação é evidente - sendo todos esses recursos tentativas de transcender o objeto [...].

Em "Braços", o referente, que dá título ao poema, dissolve-se, como afirma Lima, em "sinonímias imperfeitas que vão desfazendo o contorno do objeto" (LIMA, 1997, p. 55). Pois, se o discurso parnasiano apareceria, de algum modo, contíguo ao da racionalidade, em sua determinação de mostrar, por exemplo, que um vaso não pode extravasar a idéia comumente aceita de "vaso", Cruz e Sousa, neste poema, prescinde, em parte, de qualquer efeito de totalização da idéia:

Braços nervosos, brancas opulências, Brumais brancuras, fúlgidas brancuras, Alvuras castas, virginais alvuras, Lactescências das raras lactescências.

2 Já foi possivel notar que, nesta breve análise, estamos desconsiderando o fator étnico como vetor importante para a compreensão da obra de Cruz e Sousa. 
As fascinantes mórbidas dormências

Dos teus abraços de letais flexuras,

Produzem sensações de agres torturas,

Dos desejos as mornas florescências.

Braços nervosos, tentadoras serpes

Que prendem, tetanizam como os herpes,

Dos delírios na trêmula coorte...

Pompa de carnes tépidas e flóreas

Braços de estranhas correções marmóreas

Abertos para o Amor e para a Morte!

Caberia, aqui, uma palavra para assinalar, de passagem, a prevalência deste fetiche - os braços - em algumas (e distintas) apropriações poéticas.

Os admiráveis braços e colos alencarinos remetem à divina unidade do corpo enquanto reflexo de uma beleza interior, aparecendo, no fluxo da narração, como acessórios, ou, na visada crítica barthesiana, como motivos livres.

Já Machado de Assis, no conto "Uns braços", percorre um movimento pendular, extremamente ambíguo: ao mesmo tempo em que acentua a perfeição dos braços de D. Severina, motivo central da trama narrativa, transforma-os em um instrumento de tentação. Nesse sentido, é justa a perspicácia de Augusto Meyer ao perceber, na sensualidade dissimulada de Machado, uma inclinação de seu processo criador:

A sensualidade na obra de Machado de Assis é como um rio profundo que parece muito manso, a um golpe de vista panorâmico, e, não obstante, possui os seus segredos de correnteza, os seus caprichos de remoinhos, toda uma acidentação de longo curso. Há uma ou outra zona de transparência em que a superfície entremostra o fundo. Assim, por exemplo, com certa insistência táctil e visual matizada de fetichismo, entrega-se, não sei quantas vezes, à voluptuosa obsessão dos braços (MEYER, 1933, p. 29).

Machado mantém a censura sob sua mira e freia o caminho do desejo, localizando-o no plano da imaginação (o sonambulismo de Inácio ou de D. Severina dissimula a cena de sedução). 
Leitor e contemporâneo dè Machado, João do Rio, por sua vez, no conto "Dentro da noite", arrebata a visão mortificadora de Inácio, rompe interditos e recalques: para Rodrigo de Queirós, a loucura seria contemplar os belos braços de Clotilde e não perfurá-los com alfinetes:

Agora, a grande vontade era de espetar [os braços], de enterrar-lhe longos alfinetes, de cosê-los devagarinho, a picadas. [...] Tirei da botoeira da casaca um alfinete, e nervoso, nervoso como se fosse amar pela primeira vez, escolhi o lugar, passei a mão, senti a pele macia e enterrei-o.

Em outras incursões poéticas, Cruz e Sousa dissolve a pulsão fetichista dos braços, os quais, de maneira originalíssima, o eu poético trata por $t u$ ("teus abraços"), ou seja, como res que escuta. As sensações provocadas por esses "braços nervosos" descrevem um arco que vai do apelo à pureza ("alvuras castas", "virginais alvuras") à morte ("Dos teus abraços de letais flexuras"), com breves passagens por um paraíso libidinoso ("carnes tépidas"), aludido na expressão "tentadoras serpes", sem dúvida uma remissão à imagem bíblica do fruto proibido, tudo, é claro, dentro de um clima de indefinição rompido no final, no última verso ("Abertos para o Amor e para a Morte!"). Do ponto de vista fônico, essa série de imagens vai de par com o sentido, vago e envolvente, que habita o poema (a dualidade pureza-pecado simbolizada pelos braços): às sonoridades abertas (nervosos, marmóreas, flóreas, mornas) se justapõe, em palavras geralmente polissilábicas, uma combinação interna de sons vocálicos e consonantais (opulências, lactescências, dormências, florescências), o que deixa em aberto, com base nas considerações de Scott, algumas pistas para um possível estudo analítico-interpretativo desse recurso na poética cruz-sousiana:

Laforgue, talvez o primeiro "modernista", e uma influência fundamental sobre Eliot, emprega generosamente advérbios e adjetivos polissilábicos com o mesmo prazer de Mallarmé.

$[\ldots]$

Mas, com isso, ele ressalta a desproporção entre o peso das palavras e a intenção irreverente por trás delas [...]. 
A palavra polissilábica, pelo jogo de suas vogais modulantes, pode sugerir diversos sentidos simultâneos. Para Mallarmé, esta é a fonte de sua riqueza; para Laforgue, é um sinal de sua duplicidade e astúcia. Ela tem coisas demais a dizer para ser capaz de contar a verdade (SCOTT, 1989, p. 170).

Se tivermos em mente os demais poemas que compõem Broqueis, Faróis e Últimos sonetos, podemos perceber que, não obstante alguns belos momentos compositivos como vistos no poema acima - bem como, a nosso ver, em "Cárcere das almas", "Caminho da glória", "Esquecimento", "Flor perigosa", "Pressago", dentre outros, e em alguns poemas manuscritos do autor, como "Velho vento" e "Crianças negras" -, a ausência de variações temáticodiscursivas, o uso reiterado de uma sintaxe elíptica e a abundância de termos raros dão, por vezes, como resultado, um tom extremamente monocórdio à obra do simbolista brasileiro. Disso são exemplos as estrofes iniciais dos poemas abaixo, que soam como uma espécie de "antífonas" introdutórias ao assunto:

Eternas, imortais origens vivas

Da Luz, do Aroma, segredantes vozes,

Do mar e luares de contemplativas

Vagas visões volúpicas, velozes...

("Supremo desejo")

Alma da Dor, do Amor e da Bondade Alma purificada no Infinito, Perdão Santo de tudo o que é maldito Harpa consoladora da Saudade! ("Alma mater")
Capro e revel, com os fabulosos cornos

$\mathrm{Na}$ fronte real de rei dos reis vetustos

Com bizarros e lúbricos contornos,

Ei-lo Satã entre os Satãs augustos

("Satã")

Alta, a frescura da magnólia fresca, Da cor nupcial da flor da laranjeira, Doces tons d'ouro de mulher tudesca $\mathrm{Na}$ veludosa e flava cabeleira.

("Tuberculosa")

Essas seriam as marcas singularizadoras de sua poética, que, examinada assim, e para falar com Bosi, "recebe, em geral, tratamento platonizante e abre caminho para um dos processos psicológicos mais comuns no poeta: a sublimação" (BOSI, 1971, p. 303). 
Em contraposição a essa configuração artística, Paul Verlaine (1844-1896), figura de proa do movimento mais conhecido como simbolismo - designação, aliás, conforme se verá adiante, que o poeta aceitaria com reservas -, cultiva a sobriedade, princípio seguido à risca pelo autor de Poemas saturnianos (1866) desde o momento em que, no poema "Art poétique" ("Arte poética"), publicado em 1882 na revista "Paris moderne", contrariava, sem finalidade panfletária, o postulado parnasiano, segundo o qual um poema é bom e sério quando utiliza imagens excessivamente retóricas ("Pegue a retórica / e torçalhe o pescoço", afirma sem meias palavras). Diferentemente de Cruz e Sousa, que converte, quase sempre, a experiência das coisas em figuras místicas e imagens abstratas, Verlaine transforma a vaga impressão das coisas em sentido. Com uma linguagem econômica, pouco adjetivada, vai traçando o percurso de sua obsessão: utilizar sem rebuscamentos, e sob os efeitos da musicalidade, o vago e o nebuloso, como formas de dissolução do real:

Tua alma é uma paisagem de outros dias

Por onde, ao som de alaúdes, vão passando,

Quase tristes nas suas fantasias,

Bergamascos e máscaras dançando. ${ }^{3}$

(Apud JUNIOR, 1950, p. 422. Tradução Onestaldo de Pennaforte)

Nessa ordem de idéias, vale comentar, ainda, a citação baudelairiana, escrita no original, com a qual Cruz e Sousa, à guisa de epígrafe, abre Broquéis: "Seigneur, mon Dieu! Accordez-moi la grâce de produire quelques beaux vers qui me prouvent à moi même que je ne suis pas le dernier des hommes, que je ne suis pas inférieur à ceux que je méprise". ["Senhor, meu Deus! Concedei-me a graça de produzir alguns poucos versos que provem, a mim mesmo, que eu não sou o último dos homens, que eu não sou inferior àqueles que eu desprezo"]. Supomos - e aqui estamos em um domínio fora do poético - que, espelhado em sua própria história de vida, Cruz e Sousa pode

3 "Votre âme est un paysage choisi/ Que vont charmant masques et bergamasques/ Jouant du luth et jouant et quase/ Tristes sous leurs déguisements fantasques." No poema, bergamasques pode designar tanto os habitantes quanto as danças de Bérgamo. 
ter interpretado equivocadamente essa formulação de Baudelaire (1821-1867): o que era, para Baudelaire, um combate ao ascenso burguês - presente, metonimicamente, no enunciado "esses [homens] que eu desprezo" - passa, provavelmente, a ser entendido, por um artista pobre, negro e socialmente inferiorizado, como uma revolta solitária.

Simbolismo e decadismo francês: duas estéticas e suas (prováveis) histórias ${ }^{4}$

Inicialmente é preciso deixar claro que, quando Baudelaire publica, em 1857, suas Flores do mal (e não no final do século, conforme se vem afirmando amiúde), a denominação simbolismo não havia sido criada. Isso quer dizer que "estas flores doentias" ("ces fleurs maladives"), pois é assim, nesses termos dêiticos e metalingüísticos, que ele as dedica a Théophile Gautier (1811-1872), nascem em estado de orfandade terminológica. Em carta de agradecimento a Baudelaire, que lhe dedicara os poemas "Les petites vieilles" ("As velhinhas") e "Les sept petits vieillards" ("Os sete velhinhos"), Victor Hugo (1802-1885), entusiasmado com a liberdade formal que ele próprio propugnava, tentaria entender essa estética sem nome através de uma perífrase notável - "arrepio novo" ("frisson nouveau"): "Que fazeis ao escrever estes versos surpreendentes:"Os sete velhinhos" e "As velhinhas" que me dedicais e pelos quais vos agradeço? Que fazeis? Caminhais. Avançais. Dotais o céu da arte de não sei que raio macabro. Criais um arrepio novo." (Apud GAUTIER, 1989 , p. 133). Em outras palavras, para o autor de Os miseráveis, a temática baudelairiana de presumíveis destinos individuais - o homem, o amor, o sofrimento - vinha com uma sobrecarga poética pouco (ou jamais) explorada.

4 Estamos utilizando o termo decadismo com o intuito de guardar a terminologia original, tal como a encontramos nos textos de época consultados. Provavelmente, poetas e teorizadores pretendiam resguardar o paradigma com a palavra década. Decadentismo, termo, atualmente, em voga, mostra que a expressão da decadência não é apanágio de uma época. É um estilo mais amplo, independente do tempo e do espaço, mas que tem sempre de se revestir da mesma maneira descrente, apocalíptica, de interpretar o mundo. 
De fato, com Baudelaire inicia-se a despersonalização da lírica moderna (FRIEDERICH, 1978, p. 36-37), neutralizadora do eu empírico: mais do que um espectador de si mesmo, o poeta transformase em um espectador do mundo, e, como tal, em um ser actônico, na formulação de Walter Benjamin:

Também o poema $O$ Cisne está dedicado a Victor Hugo talvez um dos poucos cuja obra - assim parecia a Baudelaire - trazia à luz uma antiguidade nova. Tanto quanto se pode falar de uma fonte de inspiração em Victor Hugo, ela é fundamentalmente distinta da de Baudelaire. A Hugo é estranha a capacidade de atonia que - se for admissível um conceito biológico - se manifesta centenas de vezes na poesia de Baudelaire, como uma espécie de mímese da morte. Ao contrário, não se pode falar de uma predisposição actônica de Hugo (BENJAMIN, 1995, p. 82 ).

O actônico não alimenta sonhos de mudar a sociedade (ao contrário de Hugo, Baudelaire não teria uma preocupação racional com o futuro, diz Benjamin). O que define seu estado poético é o cansaço, o esgotamento, uma atitude permanentemente lúcida diante da indicibilidade do presente (em uma foto de Baudelaire, tirada por Cajart, o que atrai sobremaneira é o olhar duro, profundo, de uma fixidez assustadora, do poeta).

Não é próprio, pois, do actônico reconciliar-se com o seu entorno: as formas de dominação do capitalismo moderno. Aos valores burgueses, que a cidade hausmaniana ostenta, o poetaesgrimista (interpretação alegórica por meio da qual o pensador alemão aprofunda, dialeticamente, o pensamento de Gustave Kahn) reage com o seu "pas saccadé". Benjamin lembra que Nadar, ao falar de Baudelaire, chama a atenção para este detalhe: "[...] é o passo do poeta que erra, pela cidade, procurando ruínas; também deve ser o passo do trapeiro, que, a todo instante, pára no seu caminho, apanhando o lixo que encontra". (BENJAMIN, 1975, p. 16).

Caberia, então, a Baudelaire, sustentar o insustentável, ou seja, o impacto de uma cidade urbanizada, sem, no entanto, descrevêla - "Baudelaire não descreve nem a população, nem a cidade. Ao abrir mão de tais descrições colocou-se em condições de evocar uma 
imagem na outra", assegura-nos Benjamin (ibidem, p. 116) submetida a um racionalismo tecnológico, artificial, instituído pela nova ordem social burguesa em sua "marcha para o progresso" 5 :

Que Baudelaire se tenha colocado hostil perante o progresso foi a condição sine qua non para que pudesse dominar Paris em sua poesia. (BENJAMIN, 1995, p. 174)

É muito importante que o "novo" em Baudelaire não preste nenhuma contribuição ao progresso. Aliás, em Baudelaire, praticamente não se encontra nenhuma tentativa de entender-se a sério a noção de progresso. É sobretudo a "crença no progresso" que ele persegue com seu ódio como se ela fosse uma heresia, uma falsa doutrina e não um erro habitual. (Ibidem, p. 177).

Essa ética do desmoronamento seria percebida por Gautier, o primeiro, talvez, a definir, positivamente, um "estilo de decadência" em função de Baudelaire:

O poeta das Flores do mal gostava daquilo que se chama impropriamente o estilo de decadência, e que outra coisa não é senão a arte que chegou a esse ponto de maturidade extrema determinada a seus sóis oblíquos pelas civilizações que envelhecem [...]. Não é coisa fácil, aliás, esse estilo desprezado pelos pedantes, pois exprime idéias novas com formas novas e palavras que nunca se ouviram. De encontro ao estilo clássico, ele admite a sombra e nessa sombra movem-se [...] as fantasias obscuras [...] e tudo aquilo que a alma [...] encerra de tenebroso, de disforme, de horrivel. (GAUTIER, 1989, p. 44).

5 O termo progresso deve ser entendido em seu sentido mais vulgar, como uma soma de inovações técnicas e suas complexas implicações, encetadas pela revolução industrial inglesa ainda no final do século XVIII, apropriadas pelas demais nações européias e repassadas para os países periféricos. 
Em um procedimento que faz lembrar a análise de Gautier, Paul Bourget (1852-1935), em Théorie de la décadence (1881), percebe, em Baudelaire,

[...] o homem da decadência [que conservou] uma incurável nostalgia dos belos sonhos de seus antepassados, [que] pela precocidade de seus abusos, [esgotou], nele próprio, as fontes da vida [e julgou], com um olhar permanentemente lúcido, a incurável miséria de sua vida (Apud ADAM, 1972, p. 145). ${ }^{6}$

Porém, após as consideraç̃es de Gautier e nos anos que imediatamente sucederam ao rumoroso processo judicial e à morte de Baudelaire, fica difícil, para a nossa pesquisa, recompor teorias, propostas, pressupostos explícitos ou implícitos, indicativos dos rumos tomados pelo pensamento crítico francês, hipótese apenas confirmada pelas palavras de Pierre Martino, que, ao sublinhar o trabalho de emancipação da arte levado a termo por Verlaine, Mallarmé (1842-1898) e Rimbaud (1854-1891), situa a gênese de seus processos criadores na revolta contra a crença positivista e aponta uma data imprecisa:

Verlaine, Mallarmé, Rimbaud, apesar de suas ligações parnasianas evidentes, estão fora da tradição do Parnaso. Os três revoltaram-se. E, se buscarmos as mais profundas razões de sua revolta, perceberemos que elas lhes são comuns: eles se revoltaram, como Baudelaire, contra as realizações do espírito positivista, quer se trate de moral, de arte ou de organização social. O positivismo acreditava poder explicar o mundo, pintá-lo e regulamentá-lo: insatisfeitos com essas explicações, eles encontravam, em tudo, o enigma, o mistério, a inquietação. Essa perturbação intelectual, da qual eles foram os primeiros a advertir, aumentou, pouco a pouco, após 1870 [...]. Em todas as áreas, o positivismo havia ensejado suprimir o

6 "[...] l'homme de la décadence ayant conservé une incurable nostalgie des beaux rêves de ses aieux, ayant par la precocité des abus tari en lui les sources de la vie, et, jugeant d'un regard demeuré lucide, l'inguérissable misère de sa vie". 
mistério: por toda parte o mistério reaparecia, como uma objeção aos resultados insuficientes da ciência, ou então como uma necessidade da sensibilidade (MARTINO, 1967 , p. 120).

No âmbito da criação literária, a decadência seria posta em questão, décadas mais tarde, por Verlaine, que a menciona e a tematiza no poema "Langueur" ("Langor"), publicado, em 1884, na revista "Le chat noir" ("O gato preto"), o qual logo integraria a coletânea Jadis et naguère (1884).

Sou o império no fim da decadência

Que olha passar os grandes bárbaros brancos

Compondo acrósticos indolentes

Com um estilo de ouro onde o langor do sol dança ${ }^{8}$

A harmonia deste poema, cujo primeiro verso parece prolongar o spleen mussetiano - "Então, sobre um mundo em ruínas/ Quedou-se uma juventude ansiosa" ["Alors sur un monde en ruines / S'assit une jeunesse soucieuse"] - vem da atmosfera vaporosa (o modo como Verlaine dispõe as imagens e as dissolve corresponde à sua idéia de poesia), em meio à qual o eu poético assiste, indiferente, na posição de observador, à passagem dos altivos "bárbaros brancos", pondo-se, vale sublinhar, à distância deles.

7 "Verlaine, Mallarmé, Rimbaud, malgré leurs attaches parnassiennes évidentes, sont bien en dehors de la tradition du Parnasse. Tous trois, ils se sont revoltés; Et, si l'on cherche les raisons les plus profondes de leur révolte, on voit qu'elles leur sont communes: Ils se sont révoltés, comme Baudelaire, contre les réalisations de l'esprit positiviste, qu'il s'agit de morale, d'art ou d'organisation sociale. Le positivisme croyait bien pouvoir expliquer le monde, le peindre et le régenter: eux, insatisfaits de ces explications, ils trouvaient partout l'énigme, le mystère, l'inquiétude. Ce trouble intellectuel, dont ils étaient les premiers avertisseurs, grandit peu à peu, après 1870 [...]. Dans tous les domaines, le positivisme avait voulu supprimer le mystère: partout le mystère réaparaissait, comme une objection aux résultats insuffisants de la science, ou bien comme un besoin de la sensibilité."

8 "Je suis l'empire à la fin de la décadence/ Qui voit passer les grands barbares blancs/ En composant des acrostiches indolents/ Avec un style d'or où la langueur du soleil danse". 
Ao contemporaneizar os dois planos - o da decadência e o da barbárie - Verlaine admite, poeticamente, o aspecto antinômico do mundo, possibilitando, nos rastros de Baudelaire, a tematização do ser impotente, acicatado pela civilização. Aqui, a velha dicotomia civilização (progresso) - barbárie (decadência), em sua seqüencialidade histórica processual, inverte-se em seus opostos, desmembradas as partes distintas que a constituíam. Pois, se para os que pregavam a idéia de civilização ou progresso, bárbaros são aqueles que não se submetem a leis, para os decadentes, bárbaros são os civilizados que submetem o homem à barbárie tecnicizada, à mercantilização da arte, à regência do dinheiro, em suma.

Em Wilde e Yeats, a "decadência" se converte no termo a ser dirigido contra seus adversários. Decadentes são os que aceitam o mundo do consumo, da insensibilidade, sem imaginação, com toda sua moral, sinceridade e seriedade (ELLMANN, 1991, p. 24).

Imbuídos desse procedimento de reversão, os decadentes rompem com as convenções da linguagem poética instituída, renegam princípios platônicos, propõem uma relação analógica entre progresso e degeneração", abrindo caminhos para um "individualismo anárquico", entendido, aqui, como uma possibilidade de a arte literária, em um gesto de agressão à mimese, poder tratar de temas até então tabuizados:

[Para Bourget], um estilo de decadência é simplesmente um estilo favorável à manifestação irrestrita do individualismo estético, um estilo que rompeu com as exigências autoritárias tradicionais, tais como a unidade, a objetividade, a hierarquia, etc. A decadência, assim

9 Calinescu (1977) assinala que Désiré Nisard (em oposição a Gautier, a idéia de decadência era negativa para ele) teria sido o primeiro a introduzir a noção de decadência como um "estilo de época", mais tarde retomado, em sentido nihilista, por Nietzsche. Cf. CALINESCU, 1977, p.186. 
entendida, e a modernidade coincidem com a rejeição à tirania da tradição (Ibidem, p. 171). ${ }^{10}$

Em um procedimento análogo ao de Ellmann (1991), Calinescu (1977) persegue a questão, convergindo-a para a fórmula progresso é decadência, decadência é progresso. No primeiro argumento, progresso é decadência para aqueles que julgavam que o homem estaria superando o que tem de negativo, movimentando-se em direção ao melhor, a uma era de felicidade e viam, negativamente, a emergência de códigos literários não sancionados; no segundo argumento, inscreve-se uma postura escatológica (eschatos, em grego, significa "último"), uma idéia de negatividade: o homem, ao contrário do que previa a era de prosperidade, estaria cavalgando em direção ao pior. Cioran consolida essa capacidade de autodestruição do gênero humano:

Consideradas todas as coisas, o final do século não será o mais refinado, porém o mais apressado, século em que dissolvido seu Ser em movimento, a civilização, em um supremo impulso rumo ao pior, cairá em pedaços no redemoinho que ela própria levantou (Apud CALINESCU, 1977, p. 148).

Avançando a questão, para aqueles que produziam uma nova arte, a decadência era benéfica, porque implicava uma mudança do cânone artístico, dominado por uma arte atemporal (o parnasianismo). Vê-se então que, secularizada a idéia de decadência, tempo $e$

10 "With him [...] a style of decadence is simply a style favorable to unrestricted manifestation of aesthetic individualism, a style that has done away with traditional authoritarian requirements such as unity, hierarchy, objectivity, etc. Decadence thus understood and modernity coincide in their rejection of the tyranny of tradition." Todas as citações em inglês foram traduzidas pelo ex-professor do Departamento de Letras Estrangeiras Modernas da Ufal Dr. Luiz Gonzaga Duarte de Amorim.

11 "All things considered, the century of the end will not be the most refined or even the most complicated, but the most hurried, the century in which, it's Being dissolved in movement, civilization, in a supreme impulse toward the worst, will fall to pieces in the whirlwind it has raised". 
historicidade são fatores preponderantes para a construção poética decadista.

Transportada dos estudos históricos para a literatura (a idéia de decadência continha os mecanismos da historiografia, segundo os quais todas as sociedades passariam por um processo de formação, de apogeu e de queda), a tensão entre aquelas duas forças estéticoideológicas de configuração artística, uma tendendo para a conservação, outra para a inovação, passa a ser polemizada nas revistas (Remy de Gourmont, crítico e teórico do simbolismo, relacionaria mais de cem) e nos espaços públicos dos cafés, chaves essenciais para o entendimento do clima beligerante da época, relembrado, com nostalgia, por Valéry. Observe-se, ainda, no entrecho abaixo, um ponto-chave merecedor de atenção: trata-se da caracterização social do escritor que escreve no final do século XIX. Sem a proteção do mecenato e já beneficiados pela lei dos direitos autorais proposta por Alfred de Vigny (1797-1863), os escritores passam a viver de sua própria pena:

[Eu] entrava em um daqueles cafés, hoje quase desaparecidos, que desempenharam um papel tão importante na elaboração das inumeráveis escolas da época [...]. Os que [...] freqüentaram, mesmo pouco, esses antros luminosos e barulhentos, encontram-nos em sua memória. Revivem, com melancolia, as noites passadas entre aqueles espelhos onde musas [...] enfeitavam-se e arrumavam seus véus; entre essas mesas [nas quais], Verlaine aqui, Moréas ali, mantinham discussões terríveis sob as nuvens espessas de fumaça, no meio do tumulto dos pratos [...] e dos gritos agudos das mulheres que brigavam. Em determinado momento, houve uma escola [...] e um dogma em cada uma dessas salas privilegiadas. Fundava-se ao mesmo instante uma revista, para a qual ninguém podia prever os meios de subsistência. Mas pouco importava. O essencial era encontrar o título e redigir o manifesto [...]. Ocorria que a redação do manifesto já inflamava carta e pessoas. A metade de nossos fundadores fazia um cisma e mudava de café... (VALÉRY, 1991, p. 73). 
E como se, na maré alta do positivismo, não fossem suficientes as dissensões internas, testemunhadas por Valéry, a idéia de uma arte exprimindo a degenerescência de uma civilização entra em choque com duas escolas literárias (usamos o termo "escolas" em respeito à terminologia observada nos estudos críticos da época) coetâneas: o parnasianismo e o naturalismo. O que poderia justificar, a nosso ver, a profusão de denominações depreciativas recebidas, tanto nos meios literários parisienses quanto nos brasileiros: deliqüescentes, místicos, quintessentes, nefelibatas, esotéricos, dentre outros.

Tratava-se, finalmente, de encontrar uma denominação adequada para aquele "arrepio novo" que Victor Hugo - ele próprio considerado, nas palavras de Baudelaire, "um compositor da decadência"(apud CALINESCU, 1977, p. 165) - pressentira e que, décadas mais tarde, receberia, de um lado, muxoxos literários do "Komitê des Trois Grâces" ("Komitê das Três Graças"), formado por Théodore de Banville (1823-1891), François Coppée (1842-1908) e Anatole France (1844-1924), assim cognominados, por Verlaine, em razão de o trio ter recusado, nas revistas das quais eram editores, seus poemas e os de Mallarmé; e, de outro, surpreendia Emile Zola (18401902), ${ }^{12}$ sobretudo no momento da publicação, em 1884 , do romance $A$ rebours (Às avessas), de Joris-Karl Huysmans (George-CharlesMarie, 1848-1907), surpresa relatada, em detalhes, no "Préface écrite vingt après" ("Prefácio escrito vinte anos depois"), de Huysmans, pelo fato de o autor de Às avessas, a quem Zola era ligado por fortes laços de amizade, ter abandonado a rota do determinismo mesológico.

Neste romance, a entrada do dândi decadente se dá pela via da personagem Jean Floressas Des Esseintes, emprestada, aliás, de figuras reais, como Robert de Montesquiou e o conde D'Orsay, que deram ao autor, assim como, mais tarde, a Marcel Proust (1871-1922), inspiração e expressão. No exato momento em que a representação objetiva da realidade exterior era estabelecida pelos naturalistas, esses "fotógrafos", no dizer de Barbey d'Aurevilly (1808-1889), "sem alma e sem idéias" (apud, LIVI, 1991, p. 46), Huysmans escreve uma trama em que, rompendo com aquele preceito doutrinal, apresenta uma personagem solitária, de costas para a civilização, "longe do estéril

12 Sobre a noção de decadência em Zola, ver Calinescu (1977, p. 168). 
turbilhão das ruas" (aliás, em absoluta coerência com sua postura artística, Huysmans se enclausuraria em um mosteiro), cujas excentricidades, ao mesmo tempo em que "autentificam" sua origem aristocrática, distinguem-no dos interesses estreitos do burguês, que aparece, tão-somente, na tessitura narrativa, como derivação (respirando cultura religiosa, arte pictórica e literatura, o narrador huysmanniano não está interessado em qualquer cotejamento entre classes sociais). Presentifica-se, assim, um autêntico degustador, na apreciação feliz de Ellmann:

A decadência se diferenciava da corrupção ou do filistinismo porque se podia discuti-la não só com preocupação, mas também com gosto. Gautier, cujos textos estavam em voga tanto na França quanto na Inglaterra, afirmava em seu prefácio a Les fleurs du mal [As flores do mal], de Baudelaire, em 1868, que o espírito decadentista se harmonizava com a época. Ele interpretava a decadência como o ponto máximo da maturidade de uma civilização. Da mesma forma, em 1883, Paul Verlaine podia anunciar, mais com Schadenfreude [malícia] do que com preocupação: "Je suis l'empire à la fin de la décadence" ["Sou o império no fim da decadência"]. As culturas agonizantes são as melhores. Poucos meses depois do poema de Verlaine, surgia o romance de Huysmans, $\dot{A}$ rebours [Às avessas], para dar à decadência uma força programática. Os gostos de seu nobre decadente (os decadentes são sempre homens, e de preferência nobres; as mulheres decadentes recebem outro nome) não são comuns. Resoluto em sua busca de prazeres inauditos, o protagonista acaba ficando neurastênico, mas da espécie mais glamurosa de neurastenia. Essa obra vigorosa sobreviveu a toda prosa decadentista por ter estabelecido uma nova personagem: o degustador, que muda as bebidas constantemente e passa de uma a outra fantasia exótica e descabelada (ELLMANN, 1991, p. 12-13).

Nesse espaço de tensões do campo literário, em que escritores, independentemente das posturas poéticas que professavam, viviam em estado de semimarginalidade, tanto literária, quanto social, a polêmica toma um rumo efervescente quando Paul Bourde, em um artigo 
publicado no periódico "Le temps" ("O tempo"), propõe, pejorativamente, a designação "decadente" para a nova estética que surgia. Exemplo ilustrativo da condição social, precária, do escritor, Anatole Baju (1846-1895) - imprimindo, a crer em Gustave Khan (1902), modesta e manualmente, em sua mansarda, o jornal "Le décadent" - aceita-a com reservas:

É lamentável que os Decadentes não tenham, eles próprios, escolhido seu nome. O ridículo, com o qual tentam cobri-lo, teria sido evitado, e se tivessem sido sinceros, este nome significaria uma coisa totalmente diferente. Sem dúvida, não totalmente o contrário do que ele quer dizer, porque o espírito humano já não pode ascender mais, porém se esse nome tivesse sido bem escolhido, os Decadentes se chamariam os quintessentes [...]. Ah! Se por Decadência ouve-se falar de velhas literaturas em ruína, então estamos em plena Decadência, e os Decadentes, que têm como missão apressar esse movimento de seus antepassados até a queda, aplaude o nome que os designa (BAJU, 1886; grifos de Baju). ${ }^{13}$

Não é muito natural, convenhamos, encontrar, no decurso da história literária francesa uma polêmica dessa envergadura, que Verlaine, nos estertores de sua própria decadência física, rodeado de poucos amigos no hospital Ternon, retomaria. Para ele, a designação "simbolismo" seria insuficiente para a ambição de seu escopo literário e o termo "decadente" não the parecia, de modo algum, constrangedor. Tal como ocorrera com o termo impressionista, qualificação que,

13 "Il est regrettable que les Décadents n'aient pas eux-mêmes à faire leur choix de leur nom. Le ridicule dont on tente de le couvrir aurait été prévenu, et s'ils eussent été sinceres, ce nom signifierait tout autre chose. Sans doute pas tout à fait le contraire de ce qu'il veut dire, parce que l'esprit humain ne peut guère ascender davantage, mais s'il eût été bien choisi, les décadents s'appelleraient les quintessents [...]. Ah! Si par Décadence on entend parler des vieilles littératures en ruines, alors nous sommes em pleine D'cadence et les Décadents qui ont pour mission de hâter ce mouvement de leurs aînés vers la chute, applaudissent au nom qui les désigne". 
aplicada à pintura, em pouco tempo perderia sua conotação pejorativa original, o epíteto decadente obteve o assentimento dos poetas alvejados. Note-se, na citação abaixo, a importância atribuída à máscara e à morte, dois traços constitutivos da poética decadente:

Gosto [...] da palavra decadência, resplandescente de púrpura e de ouros. Evidentemente retiro-lhe qualquer imputação injuriosa e qualquer idéia de degradação. Ao contrário, essa palavra supõe pensamentos refinados de extrema civilização, uma cultura literária apurada, uma alma capaz de intensas volúpias. Projeta clarões de incêndio e brilho de pedrarias [...]. A decadência [...] é Petrônio mascarando com flores sua agonia. São [...] as marquesas caminhando sorrindo para a guilhotina e com o cuidado de não desmanchar o penteado. É arte de morrer em plena beleza. Foi aliás esse sentimento que me ditou o soneto que vocês conhecem:

Sou o império no fim da decadência. (Apud RAYNAUD, 1920, p. 64; grifos de Raynaud). ${ }^{14}$

Não seria demais lamentar o destino reservado para uma estética que, tendo afetado o império da racionalidade e, por conseguinte, mudado os rumos da poética francesa, ficaria guardada na gaveta da memória daqueles que a vivenciaram. Pois se Kahn afirma:

Em 1885, havia decadentes e simbolistas, muito decadentes e poucos simbolistas. A palavra decadente havia sido pronunciada, a palavra simbolista ainda não; nós falávamos de símbolo, nós não tínhamos criado a

14 "J'aime [...] le mot décadence tout miroitant de pourpre et d'ors. J'en revoque, bien entendu, toute imputation injurieuse et toute idée de déchéance. Ce mot suppose au contraire, des pensées raffinées d'extrême civilisation, une haute culture littéraire, une ame capable d'intensives voluptés. Il projette des éclats d'incendie et des lueurs de pierreries [...]. La décadence c'est [...] Pétrone masquant des fleurs son agonie. C'est [...] les marquises marchant à la guillotine avec um sourire et le souci de ne pás déranger leur coiffure. C'est d'ailleurs ce sentiment qui m'a dicté le sonnet que vous connaissez:

Je suis l'empire à la fin de la décadence" 
palavra genérica simbolismo, e os decadentes e os simbolistas eram, então outra coisa" (KAHN, 1902, p. $33-34)^{15}$

podemos supor que o período áureo do embate entre decadentes e simbolistas não ultrapassou mais de duas décadas. Na trajetória do pensamento decadente, ocorre um sutil deslocamento, uma recusa ao termo; o bloqueio teria partido de Mallarmé e, diante de seu prestígio nos círculos literários, a designação simbolismo seria assimilada.

Obcecado pelo seu projeto estético de dissolução da idéia, Mallarmé, convicto de que a música seria a única arte capaz de apagar a significação e, por conseguinte, de jamais perder sua autonomia frente ao mundo alienado do capital, teria sugerido a denominação simbolismo a Jean Moréas (Johannés Papadiamentopoulos, 18561910). Estudando o manifesto de Moréas, Martino ressalta a empolgação de seu autor, diante das abstrações mallarmenianas ${ }^{16}$ :

Um manifesto de Moréas, no Figaro (18 de setembro de 1886) define o simbolismo [...]; sua definição é abstrata demais: insiste na vontade, bem mallarmeniana, de fazer desaparecer a realidade diante da Idéia (MARTINO, 1967, p. 130). ${ }^{17}$

Em sua existência meteórica, a postura decadente mostrou, na tensão dialética própria a seu tempo (o que não nos impede de trazer o dilema para nossa contemporaneidade, para dentro, por exemplo, do pensamento crítico adorniano), que decadência e progresso não são termos conflitantes: a decadência está no bojo da civilização e vice-

15 "En 1885, il y avait des décadents et des symbolistes, beaucoup de décadents et peu de symbolistes. Le mot décadent avait été prononcé, celui de symboliste pas encore; nous parlions de symbole, nous n'avions pas crée le mot générique de symbolisme, et les décadents et les symbolistes c'était tout autre chose, alors."

16 Por uma simples questão de sonoridade, preferimos o qualificativo mallarmeniano/mallarmeniana a mallarmaico/mallarmaica.

17 "Un manifeste de Moréas (18 septembre 1886) définit le symbolisme [...]; sa définition est fort abstraite: elle insiste sur la volonté mallarméenne, de faire disparaître la réalité devant l'Idée". 
versa. Em termos teóricos mais amplos, o termo Simbolismo passou a abarcar o de Decadismo. Solidões distintas, nascidas da insatisfação com a herança ocidental capitalista, decadentes e simbolistas, de todo modo, confrontaram-se com os paradigmas esboçados pelo parnasianismo, propuseram novos rumos para a arte, e uniram-se, finalmente, no sentimento comum de não se perceberem cúmplices da civilização.

\section{Literatura de casaca, luvas, gravata branca e peitilhos em goma}

Essas concepções poéticas vinham da França, onde tinham surgido como resultado de processos econômicos, sociais e culturais que ainda não haviam começado no Brasil. Como o país não havia adotado processos de produção mecanizada, era-lhe de todo desconhecida a experiência do progresso que só se daria com o aparecimento controverso da máquina. No Brasil, o industrialismo, observa Florestan Fernandes, ocorreria através de demorados processos de reinterpretação e de reintegração cultural pouco produtivos operados pelas classes dirigentes, ainda atreladas à tradição agrária, escravocrata, caracterizadora de nosso "antigo regime" (FERNANDES, 1960). Considere-se, então, que, salvo engano, somente a partir do princípio do século XX, formula-se historicamente a possibilidade de um debate sobre o assunto, cujo epicentro conceitual, à falta de outro, seria o polêmico projeto de urbanização do Rio de Janeiro - elo, decerto, de uma complexa cadeia de fatores -, condensado na conhecida fórmula "O Rio civiliza-se", lançada por Figueiredo Pimentel, o qual ganharia ramificações, logo estendidas para esta construção, em excesso, da auto-estima nacional a que se deu o nome de ufanismo.

Decerto o desvio do cânone literário francês, proposto pelo decadismo e pelo simbolismo, corresponde a contingências históricosociais determinantes para seu surgimento, pois, mesmo não havendo uma relação de causalidade externa entre literatura e sociedade, como reflete Candido em seus diversos estudos críticos, uma mudança formal pode eventualmente corresponder a necessidades históricas preexistentes. Por mais influente que foi em nossas letras, o movimento simbolista não poderia revestir-se da gravidade necessária para representar o peso da angústia, o declínio, a degenerescência de uma civilização, pois esse seria o fundamento, essa a posição 
gnosiológica dos poetas decadentes. De nossa condição de "literatura transplantada", subsidiária da européia,

Considerada em bloco, e sem penetrarmos em sua realidade essencial e efetiva, que é sempre o indivíduo, é certo que não tivemos em nossa história uma literatura espontânea, que viesse a lume naturalmente, como produto do solo em que nascia e como frutificação natural da civilização em marcha. Tivemos, pelo contrário, e à semelhança das instituições sociais, uma literatura transplantada (ATHA YDE, 1922, p. 113).

Surge, assim, a necessidade de aceitar, sem reflexões mais profundas, o empréstimo da poética simbolista e de acompanhar a cultura francesa de referência. Carollo, com a agudeza que the é própria, percebe uma ausência de sistematização:

São informações e incitamentos nem sempre esclarecedores sobre o decadismo e o simbolismo na França, obtidos através do acesso a revistas e jornais ou da leitura de algumas poucas obras que dificilmente poderiam permitir uma visão satisfatória das novas posições (CAROLLO, 1980, p. 81).

À luz dessas anotações, é possível entender por que o debate teórico perde-se em juízos azedos, em um conjunto de informações ditas a esmo, não indo além de considerações genéricas, nem por isso impertinentes e incontroversas:

Como, aliás, em França, "decadentes" (aqui curiosamente e com intenção pejorativa cognominados "nefelibatas", expressão tirada de Rabelais) e simbolistas não aparecem em posição bem discriminada. Guerra Barroso, Alphonsus de Guimaraens, Colatino Barroso, José Gilbcke, Silveira Netto, Dario Veloso, Gonzaga Duque foram predominantemente "decadentes"; Cruz e Souza, Emiliano Perneta, Edgar Mata, Ernani Rosas, propriamente simbolistas. Ainda assim, ao acaso, pois seria um tanto pueril fixar, sem mais detido exame e muito matizamento, as experiências individuais do movimento, em esquemas rígidos (COUTINHO, 1959, p. 224-225). 
Causar efeito era tudo. Na ausência absoluta de sentimento e de idéia, sem sinceridade e sem nobreza, todos se distraiam a confinar-se no meio da turba desorientada, por denominações de escolas, cada qual mais extravagante: uns eram simbolistas, outros decadistas, outros místicos, ainda outros instrumentistas, magníficos, satanistas etc.. E o domínio da extravagância era medonho! Os simbolistas desequilibraram os melhores espíritos, desde o momento em que ficaram no seu subjetivismo doentio e estéril, fechados para a vida, a olhar o mundo de muito longe, lá das profundezas do isolamento a que preferiram condenarse (CARVALHO, 1907, p. 219-220).

Tanto no que diz respeito à prática poética quanto à construção de um repertório crítico, divulgado em grande parte nas revistas e nos cenáculos curitibanos, o simbolismo brasileiro, porque deixou de encarnar a ideologia estética que, originalmente, o compunha, conforme mostrado, só poderia revelar-se, em nossos meios, "um tanto disparatado, complicado na dicção e confuso nas idéias"(CARVALHO, 1929, p. 388). Com isso, abriu margem para apropriações satirizantes, como nesta humorística "Canção da despedida", de Brant Horta:

Eu vou dar a Despedida

Como deu o cão pelado;

Quanto mais verga o alfinete,

Tanto mais corta o machado.

(Canivete e Bisneto Fouce)

Já fui dos bons poetas

Da escola nefelibata

E tinha visões diletas

Flagrantes Visões de Prata.

E teci muitas Quadras portentas

Cuja forma era - Cor de cristais

E apesar de não Ter Pensamentos

Compus versos Azuis, siderais. 
Meus versos tinham Termos pomposos,

Rimas raríssimas e não poucas;

Seriam mesmo Versos formosos

Se não os ornassem Palavras ocas.

Versos,

Diversos,

Cristalinos,

Extraordinários,

Lembrando Baladas

Executadas

Em violinos

Extradivários

Lembrando sons de corda de uma flauta Incauta,

Acompanhada pelo sopro etéreo

De um saitério,

Boiando à Luz de um Luar insone,

No pícaro de um monte.

E fiz Quadras Radiantes,

De Versos bons e fortes,

Com ânsias de Bacantes

Em trêmulas coortes..

Que falam de Monjas de lívidas faces,

Do Azul, da Harmonia, de Morte e Mistérios,

De Véus e Grinaldas, de Sonhos fugaces,

De Círios, de Estrelas, de Aromas etéreos.

Mas um dia me vi tão perseguido

De Termos e de Rimas tão veementes,

E da loucura ouvi tão perto o ruído

Que mandei ao Diabo os Decadentes.

(Apud MURICY, 1950)

Incorporando o processo civilizatório a partir de imagens mais incutidas pela sua própria historicidade do que pelo simples prazer da imitação e sempre atento à sua sincronicidade, João do Rio (18811921) propõe algo mais do que meras considerações estilísticas, pois 
percebe, na poesia simbolista brasileira, um movimento acriticamente herdado, uma celebração do mundo do requinte desfrutado pelos bemnascidos, algo estático sem possibilidades de interpretação de nossa cultura:

O movimento simbolista, meus senhores, não será jamais um movimento popular. Literatura de casaca, luvas, gravata branca e peitilhos em goma, é apenas um gostoso recreio, um desfastio para refinados espíritos, para privilegiadas elites de uma estouvada geração. Literatura de estufa, planta para vaso em aquecidos salões. Acabará como as begônias do equador [sic] que não podem viver senão sob os auspícios tutelares de uns certos graus de calor e de umidade (Apud EDMUNDO, 1958, p. 562).

De posse de uma literatura congenitalmente marcada por problemas de identidade e por valores culturais em aquisição, desconhecíamos as estruturas sociais, morais e mentais que concorreram à constituição do espírito moderno inaugurado pela poética decadista. Sem a pretensão de estabelecer juízos precisos, levantamos uma hipótese: talvez a pouca eficácia do simbolismo brasileiro não se deva apenas à força bloqueadora de um movimento opositor e coetâneo, o parnasianismo, já que este tivera na França igual êxito, mas sobretudo à ausência de situações históricas que obstacularizaram o escoamento ou a incorporação crítica de seu arcabouço conceitual. A ser admitido, esse pressuposto nos conduz a repetir, com Bilac, em entrevista dada a João do Rio no livro $O$ momento literário: "Nós nos regulamos pela França. A França não tem lutas de escolas, nós também não; a França tem alguns moços extravagantes, nós também". Estávamos, como se vê, em um momento de referências literárias incertas.

\section{Referências}

ADAM, Antoine et alli. Littérature française: XIX et XXème siècles. v. 2. Paris: Larousse, 1972.

ATHAYDE, Tristão de. Antecedentes e analogias. In: ATHAYDE, Tristão de Afonso Arimos. Rio de Janeiro: Anuário do Brasil; Lisboa: Serra Nova; Porto: Renascença, 1922. p. 113-124. 
BALAKIAN, Anna. O Simbolismo. Tradução José Bonifácio A. Caldas. São Paulo: Perspectiva, 2000.

BAJU, Anatole. Quintessence. In: "Le décadent", 28, setembro 1886. BENJAMIN, Walter. Charles Baudelaire - um lírico no auge do capitalismo. Tradução José Martins Barbosa e Hemerson Alves Baptista. São Paulo: Brasiliense, 1995.

BENJAMIN, Walter. A modernidade e os modernos. Tradução Heindrun Krieger Mendes da Silva, Arlete de Brito e Tânia Jatobá. Rio de Janeiro: Tempo Brasileiro, 1975.

BOSI, Alfredo. O simbolismo. In BOSI, Alfredo. História concisa da literatura brasileira. 2. ed. São Paulo: Cultrix, 1971. p. 293-336.

BOSI, Alfredo. Introdução. In BOSI, Alfredo. Araripe Júnior: teoria, crítica e história literária. Rio de Janeiro: Livros Técnicos e Científicos; São Paulo: Editora da Universidade de São Paulo, 1978. p. IX-XX.

CALINESCU, Mattei. The idea of decadence. In: CALINESCU, Mattei. Faces of modernity. Bloomington and London: University Press, 1977. p. 149-211.

CANDIDO, Antonio; CASTElLO, José Aderaldo. Realismo, Parnasianismo, Simbolismo. In: CANDIDO, Antonio. Presença da literatura brasileira - do Romantismo ao Simbolismo. São Paulo: Difel, 1976.

CARPEAUX, Otto Maria. Pequena bibliografia critica da literatura brasileira. Rio de Janeiro: Ministério da Educação e Cultura e Saúde, 1953.

CAROLlO, Cassiana Lacerda. Decadismo e Simbolismo no Brasil: crítica e poética. Brasília: Instituto Nacional do Livro, 1980. 2 v.

CARVALHO, Elysio de. João do Rio. In: CARVALHO, Elysio de. As modernas correntes estéticas na literatura brasileira. Rio de Janeiro: Garnier, 1907, p. 121-140.

CARVALHO, Ronald de. Cruz e Sousa e os decadentes. In: CARVALHO, Ronald de. Pequena história da literatura brasileira. 13.ed. Rio de Janeiro: Briguiet, 1929. cap. X. p. 334-358.

COUTINHO, Afrânio. Presença do Simbolismo. In: COUTINHO, Afrânio. A literatura no Brasil. Rio de Janeiro: São José, 1959. p. 125-226. 
EDMUNDO, Luiz. João do Rio. In: EDMUNDO, Luiz. De um livro de memórias. Rio de Janeiro: Departamento de Imprensa Nacional, 1958. v. 2. p. 561-567.

ELLMANN, Richard. Os usos da decadência. In: ELLMANN, Richard. Ao longo do riocorrente. Tradução Denise Bottmann. São Paulo: Scwarcz, 1991. p. 11-28.

FERNANDES, Florestan. Obstáculos extra-econômicos à industrialização no Brasil. In: FERNANDES, Florestan. Mudanças sociais no Brasil. São Paulo: Difusão Européia do Livro, 1960. p. 5383.

FRIEDERICH, Hugo. Estrutura da lírica moderna. São Paulo: Duas Cidades, 1978.

GAUTIER, Théophile. Baudelaire. Tradução Mário Laranjeira. São Paulo: Boitempo, 2001.

JUNIOR, Magalhães. Antologia dos poetas franceses (do século XV ao século XX). Rio de Janeiro: Tupy, 1950.

KAHN, Gustave. Symbolistes et décadents. Paris: Léon Vanier, 1902.

LIMA, Roberto Sarmento. O circulo e a palavra: constantes do poema lírico. Maceió: Edufal, 1997.

LIVI, François. A rebours et l'esprit décadent. Paris: Nizet, 1991.

MARTINO, Pierre. Du parnasse au symbolisme. Paris: Colin, 1967.

MEYER, Augusto. Da sensualidade na obra de Machado de Assis. In: "Lanterna verde", 1, 1933. p. 25-37.

MURICY, Andrade. Panorama do movimento simbolista brasileiro. Rio de Janeiro: Departamento de Imprensa Nacional, 1952.

RAYNAUD, Ernest. La mêlée symboliste. Paris: La Renaissance du Livre, 1920.

SCOTT,Clive. Simbolismo, decadência e impressionismo. In: BRADBURY, Malcolm; McFARLANE, James. Modernismo: guia geral. Tradução Denise Bottmann. São Paulo: Schwartz, 1989. p. 166185.

VALÉRY, Paul. Existência do simbolismo. In: VALÉRY, Paul. Variedades. BARBOSA, João Alexandre (org.). Tradução Maiza Martins de Siqueira. São Paulo: Iluminuras, 1991. p. 63-77. 